\title{
SUSTAINABILITY CONSUMPTION: PERUBAHAN PERILAKU MENGONSUMSI DAGING
}

\author{
Waluyo Budi Atmoko \\ Fakultas Ekonomi, Universitas Setia Budi \\ waluyobudiatmoko@yahoo.co.id \\ Nang Among Budiadi \\ Fakultas Ekonomi, Universitas Setia Budi \\ nangamongbudiadi@gmail.com
}

\begin{abstract}
Excessive meat consumption has negative impact on many areas of life, such as: health, production efficiency, environment, and social and ethics. This negative impact has encouraged the effort to change the behavior in consuming meat. This study is expected to contribute to the creation of public awareness, the need to establish the balance between consuming meat behavior and its consequences. The study used the experimental method. Hypothesis tested by Kruskal-Wallis test and Mann-Whitney test. The result of the study stated there was a significant difference between stimuli of information about negative impact of meat consumption on health, environment, social and ethics and control. Meanwhile, there was no significant difference between stimuli of information about negative impact of meat consumption on production efficiency and control. Conclusion of the study is information about negative impact of meat consumption on health, environment, social and ethics can cause behavioral change
\end{abstract}

Keywords: behavioral change, meat consumption, classical conditioning

\begin{abstract}
ABSTRAK
Konsumsi daging berlebihan berakibat negatif pada berbagai bidang kehidupan, yaitu: kesehatan, efisiensi produksi, lingkungan, sosial dan etika. Besarnya dampak negatif ini telah mendorong upaya merubah perilaku mengonsumsi daging. Penelitian diharapkan memberikan sumbangan bagi terciptanya kesadaran masyarakat, perlunya membangun keseimbangan antara perilaku mengonsumsi daging dan akibat-akibat yang ditimbulkannya. Penelitian dilakukan dengan menggunakan metoda eksperimen. Rangsangan penelitian berupa informasi dampak negatif mengonsumsi daging pada kesehatan, efisiensi produksi, lingkungan, serta sosial dan etika. Hipotesis diuji dengan uji Kruskal-Wallis dan uji Mann-Whitney. Hasil penelitian menyatakan ada beda signifikan antara rangsangan berupa informasi tentang dampak negatif mengonsumsi daging pada kesehatan, lingkungan, serta sosial dan etika dan kontrolnya. Sementara, tidak ada beda signifikan antara rangsangan informasi dampak negatif mengonsumsi daging pada efisiensi produksi dan kontrolnya. Simpulan penelitian adalah informasi tentang dampak negatif mengonsumsi daging pada kesehatan, lingkungan, serta sosial dan etika mampu menghasilkan perubahan perilaku.
\end{abstract}


Kata kunci: perubahan perilaku, konsumsi daging, pengondisian klasik

\section{PENDAHULUAN}

Persoalan kesejahteraan manusia, hewan dan lingkungan kalau ditarik mundur, tentu berakar pada masalah konsumsi Carrington et al. (2005). Timbulnya berbagai penyakit baru, terjadinya pemanasan global, eksploitasi sumber-sumber alam secara besar-besaran, serta perlakuan yang tidak etis terhadap hewan, telah menimbulkan masalah keberlanjutan (sustainability) kehidupan (Miniero et al., 2014). Salah satu jenis konsumsi yang menyumbang semakin menguatnya ancaman kepada kesejahteraan manusia, hewan dan lingkungan adalah konsumsi daging.

Konsumsi daging pada satu sisi mempunyai dampak positif, namun di sisi lain juga membawa dampak negatif, baik dalam tingkat individu maupun sosial. Kandungan nutrisi yang padat dan terkait dengan kekayaan dalam masyarakat, menjadikan daging menjadi sumber makanan yang disukai. Konsumsi daging dipertimbangkan sebagai sebuah posisi baik, yang menandakan rangking pribadi dalam hirarki sosial (Hirsch dalam Frank, 2007). Hubungan antara konsumsi daging dan posisi baik dalam masyarakat ini, terkait dengan kebutuhan seseorang untuk mendapatkan status dalam lingkungan sosialnya.

Konsumsi daging juga berdampak negatif pada kesehatan, efisiensi produksi rendah, kerusakan lingkungan, serta masalah sosial dan etika. Kerusakan lingkungan yang terkait dengan konsumsi daging antara lain: penggundulan hutan dan perusakan padang rumput, penipisan air tanah, pembuangan limbah cair, pemanasan global dan kepunahan keaneka-ragaman hayati (Frank 2007).

Dalam segmen usia tertentu, misal usia di atas 40 tahun, mengonsumsi daging mempunyai dampak negatif lebih besar daripada segmen lainnya. Daging mengandung kolesterol tingkat tinggi yang mengondisikan serangan jantung (Frank 2007). Konsumsi daging juga terkait dengan obesitas, serangan jantung dan penyakit kronis lainnya (Smil 2002). FAO dan UNDP Smil (2002) melaporkan adanya korelasi antara rata-rata pasokan daging per kapita dan harapan hidup. Studi dilakukan di 30 negara, dan hasilnya disajikan dalam Gambar 1.

Produksi daging merupakan metoda tak efisien dalam memproduksi kalori dan nutrisi yang diperlukan oleh manusia (Frank 2007). Diperlukan input lebih besar untuk menghasilkan sejumlah protein hewani daripada untuk menghasilkan protein nabati. Untuk menghasilkan satu pon protein hewani diperlukan sekitar seratus kali air (Frank 2007) dan sebelas kali bahan bakar fosil lebih banyak (Joyce et al., 2012) daripada memproduksi satu pon protein nabati 


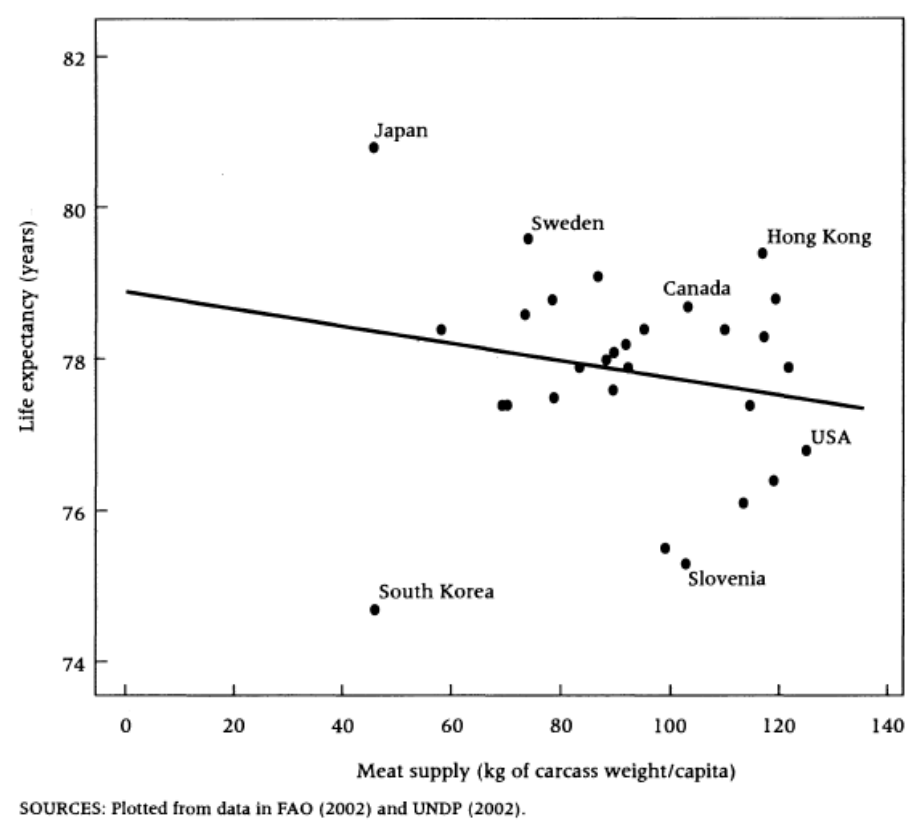

Gambar 1

Korelasi Harapan Hidup dan Rata-Rata Suplai Daging per Kapita di 30 Negara (Smill 2002)

Dalam metoda budidaya ternak intensif, produksi daging merupakan sebuah kontributor penting terjadinya polusi air tanah (Frank 2007). FAO Koneswaran dan Nierenberg (2008) menyatakan bahwa sektor budidaya hewan memancarkan 18 persen dari keseluruhan emisi gas rumah kaca (karbondioksida, metana dan nitrooksida) yang dipancarkan manusia. Gas-gas rumah kaca ini telah diketahui secara luas mengakibatkan terjadinya pemanasan global.

Budidaya hewan dalam peternakan modern mempunyai konsekuensi negatif pada bidang sosial. Pemakaian antibiotika berlebihan pada hewan ternak mengakibatkan bakteri menjadi kebal antibiotik. Bila bakteri menginfeksi manusia, maka penderita harus berjuang lebih keras untuk sembuh. Produk hewan dapat menyebarkan virus ke dalam populasi manusia, misal: $S A R S$, flu burung dan virus babi. Konsumsi daging juga mempunyai konsekuensi etis bagi manusia. Ada tuntutan etika yang semakin menguat atas tindakan manusia pada hewan.

Sejumlah persoalan yang mengemuka di atas, telah melahirkan pemikiran perlunya membangun pola konsumsi yang menempatkan keberlanjutan kehidupan sebagai inspirasi utamanya. Dalam konteks konsumsi daging, konsumsi keberlanjutan yang hendak dibangun adalah mengurangi konsumsi daging. Permasalahan yang mendasar adalah bagaimana mengubah perilaku mengonsumsi daging. Diperlukan rekayasa keperilakuan untuk mengubah perilaku mengonsumsi daging. Dalam upaya mengubah perilaku mengonsumsi daging, maka penelitian bertujuan menciptakan rangsangan yang mampu mengubah atau menurunkan perilaku mengonsumsi daging. Rangsangan yang diuji berupa informasi tentang dampak negatif mengonsumsi daging pada kesehatan, efisiensi produksi, lingkungan, serta sosial dan etika. Kontribusi 
penelitian ini bagi masyarakat dan dunia bisnis adalah: pertama, memberikan masukan bagi para pemasar produk industri vegetarian, misalnya: rumah makan vegetarian, produk tiruan pengganti daging dan sebagainya, dalam membangun strategi komunikasi pemasaran dalam upaya membujuk konsumen agar berperilaku tidak mengonsumsi daging dan beralih mengonsumsi produk pengganti daging. Kedua, memberikan masukan pada konsumen, para pemerhati dan pegiat penanggulangan gangguan kesehatan akibat mengonsumsi daging, misalnya: hipertensi, serangan jantung, diabetes, obesitas dan gangguan kesehatan lainnya, dalam membuat strategi kampanye hidup sehat terhindar dari serangan penyakit akibat mengonsumsi daging secara berlebihan.

\section{KAJIAN PUSTAKA DAN PERUMUSAN HIPOTESIS}

\section{Perilaku Mengonsumsi Daging}

Perubahan perilaku dapat dijelaskan oleh teori pengondisian klasik (classical conditioning). Pengondisian klasik didefinisikan sebagai sebuah proses yang mana rangsangan dikondisikan dipasangkan dengan rangsangan tak dikondisikan, menimbulkan tanggapan sama dengan tanggapan awal yang ditimbulkan oleh rangsangan tak dikondisikan (Nord \& Peter 1980); (Van den Hout \& Merckelbach 1991).

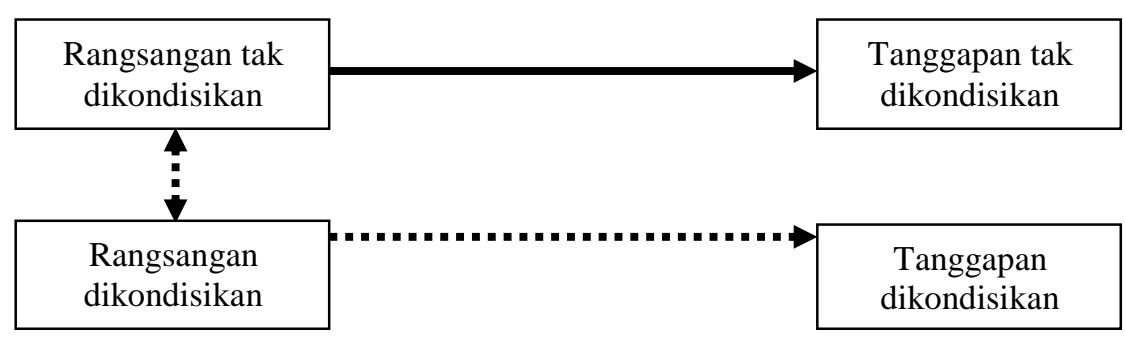

Gambar 2

Proses Perubahan Perilaku Menurut Teori Pengondisian Klasik (Assael 2004)

Dalam upaya mencapai kesamaan antara tanggapan dikondisikan dan tanggapan tak dikondisikan, maka rangsangan dikondisikan harus mendahului rangsangan tak dikondisikan (Bierley et al., 1985; McSweeney \& Bierley, 1984). Kaitan antara rangsangan dikondisikan dan tanggapan dikondisikan dicapai melalui pengulangan hubungan antara rangsangan tak dikondisikan dan rangsangan dikondisikan.

Dalam pengondisian klasik, tanggapan dikondisikan terjadi secara otomatis Allen dan Madden (1985) melalui pemberian rangsangan dikondisikan yang dipasangkan dengan rangsangan tak dikondisikan. Perubahan perilaku terjadi tanpa kesadaran dan otomatis, akibat pengulangan paparan pasangan rangsangan dikondisikan dan rangsangan tak dikondisikan. Pernyataan Brewer di atas sejalan 
dengan pernyataan Staatses dalam Allen dan Madden (1985), bahwa pengondisian terjadi tanpa kesadaran atau kognisi. Seseorang tidak secara normal sadar, bagaimana perasaan memengaruhi penilaian dan perilakunya (Allen \& Madden 1985). Pernyataan ini melengkapi pemikiran sebelumnya, bahwa dalam ketidak sadaran, maka perasaan mengondisikan terbentuknya perilaku. Zajonc (1980) menyatakan bahwa reaksi afektif dapat terjadi tanpa partisipasi proses kognitif.

McSweeney dan Bierley (1984) menyatakan, ada lima faktor yang dapat menyebabkan tidak terjadinya tanggapan dikondisikan, yaitu: overshadowing, blocking, efek pra-paparan rangsangan tak dikondisikan (US Pre-Exposure Effect), penghambatan laten (laten inhibition) dan efek Garcia (Garcia effect).

\section{Overshadowing}

Overshadowing terjadi bila dua rangsangan dikondisikan disajikan dalam waktu bersamaan dan keduanya mendahului rangsangan tak dikondisikan. Bila salah satu rangsangan dikondisikan lebih menonjol dari lainnya, maka pengondisian akan terjadi akibat rangsangan yang lebih menonjol tersebut. Masalah overshadowing diatasi dengan cara membuang rangsangan yang kurang menonjol dari paparan.

\section{Blocking}

Blocking terjadi bila partisipan pernah mengalami rangsangan dikondisikan pertama yang memprediksi tanggapan dikondisikan. Kemudian rangsangan dikondisikan pertama ini disajikan bersama dengan rangsangan dikondisikan kedua dan kemudian dilanjutkan dengan rangsangan tak dikondisikan. Sebagai hasilnya, pengondisian tidak terjadi akibat rangsangan dikondisikan kedua. Pengalaman dengan rangsangan dikondisikan pertama memblok pengondisian terhadap rangsangan dikondisikan kedua. Blocking diatasi dengan cara tidak menggunakan rangsangan tak dikondisikan yang akrab dengan subjek.

\section{Efek Prapaparan Rangsangan Tak Dikondisikan}

Pengondisian tidak akan terjadi bila subjek diberi paparan rangsangan tak dikondisikan sendirian. Bila terjadi efek pra-paparan rangsangan tak dikondisikan, maka rangsangan yang akrab dengan subjek harus tidak digunakan sebagai rangsangan tak dikondisikan. Keakraban dengan rangsangan tak dikondisikan, akan menurunkan keefektifan prosedur pengondisian klasik dalam mengubah perilaku konsumen.

\section{Penghambatan Laten}

Penghambatan laten terjadi bila rangsangan dikondisikan disajikan berkali-kali tanpa rangsangan tak dikondisikan dan ketika rangsangan dikondisikan dilanjutkan dengan rangsangan tak dikondisikan, maka kecil kemungkinan terjadi pengondisian.

\section{Efek Garcia}

Efek garcia menyatakan bahwa keengganan (tanggapan dikondisikan) dengan mudah dikondisikan oleh cita rasa (rangsangan dikondisikan pertama) dan dilanjutkan 
dengan kesakitan (rangsangan tak dikondisikan pertama). Keengganan tidak terjadi akibat cita rasa (rangsangan dikondisikan pertama) yang dilanjutkan dengan kejutan (rangsangan tak dikondisikan kedua). Demikian juga, keengganan (tanggapan yang dikondisikan) terjadi akibat cahaya dan kebisingan (rangsangan dikondisikan kedua) yang dilanjutkan dengan kejutan (rangsangan tak dikondisikan kedua). Keengganan tidak terjadi akibat cahaya dan kebisingan (rangsangan dikondisikan kedua) yang dilanjutkan dengan kesakitan (rangsangan tak dikondisikan pertama).

Keefektifan rangsangan dalam menghasilkan perubahan perilaku bergantung pada bagaimana rangsangan itu diciptakan dan pesan dalam rangsangan dibingkai. Pesan harus dibingkai sedemikian rupa, sehingga menghasilkan tanggapan yang diinginkan. Pembingkaian pesan yang menekankan keadaan positif, akan menghasilkan keputusan positif, sehingga akan mendorong penolakan risiko (Benford \& Snow 2000; Keller et al., 2003; Puto 1987). Oleh karena itu, pesan harus dibingkai secara positif, sehingga mendorong konsumen untuk menghindari risiko terjadinya dampak negatif mengonsumsi daging.

Dalam upaya merubah perilaku konsumen dalam mengonsumsi daging, maka diajukan hipotesis: rangsangan berupa informasi tentang dampak negatif mengonsumsi daging pada kesehatan, efisiensi produksi, lingkungan, serta sosial dan etika, mampu merubah perilaku konsumen dalam mengonsumsi daging. Model perubahan perilaku konsumen dalam mengonsumsi daging disajikan dalam Gambar 3.

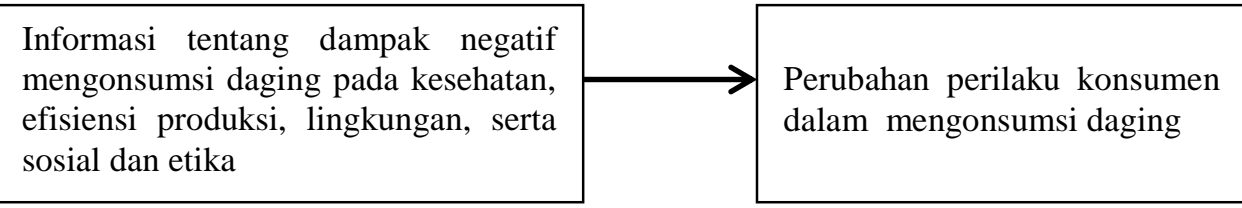

Gambar 3

Model Perubahan Perilaku Konsumen dalam Mengonsumsi Daging

\section{METODA PENELITIAN}

\section{Desain Penelitian}

Penelitian dilakukan dengan pendekatan eksperimen. Desain eksperimen adalah posttest-only control group design. Eksperimen melibatkan satu grup kontrol dan empat grup eksperimen. Diasumsikan terdapat variasi di antara lima grup tersebut, sehingga desain yang sesuai adalah desain antar subjek (between-subject design). Para partisipan dikelompokkan ke dalam satu grup kontrol dan empat grup eksperimen melalui proses random assignment.

\section{Variabel dan Pengukurannya}

Variabel terikat adalah perubahan perilaku konsumen dalam mengonsumsi daging. Perubahan perilaku konsumen dalam mengonsumsi daging didefinisikan sebagai tanggapan terhadap rangsangan dampak negatif mengonsumsi daging pada 
kesehatan, efisiensi produksi, lingkungan, serta sosial dan etika. Perubahan perilaku diukur oleh timbulnya perilaku tidak mengonsumsi daging. Variabel bebas adalah rangsangan, yang didefinisikan sebagai paparan informasi yang berisi dampak negatif mengonsumsi daging pada kesehatan, efisiensi produksi, lingkungan, serta sosial dan etika dan ajakan untuk mengurangi konsumsi daging.

\section{Partisipan Penelitian}

Partisipan dalam penelitian ini adalah mahasiswa Universitas Setia Budi. Oleh karena penelitian ini bertujuan mengubah perilaku mengonsumsi daging, maka kriteria utama bagi partisipan adalah tidak berpantang daging. Eksperimen melibatkan empat kelompok eksperimen dan satu kelompok kontrol. Penentuan kelompok eksperimen didasarkan pada empat rangsangan, yaitu paparan informasi yang berisi dampak negatif mengonsumsi daging pada kesehatan, efisiensi produksi, lingkungan, serta sosial dan etika. Setiap kelompok eksperimen dan kontrolnya terdiri dari tiga partisipan, masing-masing ditentukan melalui proses random assignment.

\section{Metoda Pengumpulan Data}

Proses pengumpulan data dilakukan melalui tahapan: penciptaan rangsangan dan pelaksanaan eksperimen. Keefektifan rangsangan bergantung pada isi, struktur, bentuk dan sumber pesan. Isi, struktur, bentuk dan sumber pesan dari rangsangan ditentukan melalui diskusi grup fokus. Dalam upaya menghindari overshadowing effect, rangsangan tak dikondisikan divariasi menjadi empat rangsangan berdasarkan dampak negatif mengonsumsi daging pada kesehatan, efisiensi produksi, lingkungan serta sosial dan etika.

\section{Analisis Data}

Data penelitian ini adalah informasi perubahan perilaku berupa perilaku tidak mengonsumsi daging atau perilaku mengonsumsi daging. Data kategorikal semacam ini tidak dapat didistribusikan secara normal. Oleh karena itu, pendekatan analisis yang lebih tepat adalah menggunakan metoda nonparametrik. Alat analisis data yang sesuai untuk menguji hipotesis adalah uji Kruskal-Wallis dan uji Mann-Whitney. Uji KruskalWallis digunakan untuk menguji beda keseluruhan diantara kelompok eksperimen dan kontrol. Uji Mann-Whitney digunakan untuk menguji beda spesifik di antara pasangan perlakuan penelitian.

\section{Cek Manipulasi}

Cek manipulasi adalah upaya untuk mengukur secara tidak langsung apakah manipulasi variabel bebas mampu memprediksi terjadinya tanggapan dikondisikan. Prediksi perubahan perilaku dilakukan dengan cara peneliti mengajukan pertanyaan untuk mengukur niat mengonsumsi daging. Alat ukur menggunakan skala nominal yang menghasilkan jawaban ya atau tidak untuk niat mengonsumsi daging. Hasil uji serentak dengan uji Kruskal-Wallis menyatakan ada beda signifikan diantara rangsangan penelitian termasuk kontrolnya (Chi-square=11,500, p<0,05). Beda 
perilaku spesifik antar pasangan rangsangan diuji dengan uji Mann-Whitney. Rangsangan berupa informasi tentang dampak negatif mengonsumsi daging bagi kesehatan, serta sosial dan etika berbeda secara signifikan dengan kontrolnya $(\mathrm{U}=0,000 ; \mathrm{p}<0,005$ dan $\mathrm{U}=0,000 ; \mathrm{p}<0,005)$. Rangsangan berupa informasi tentang dampak negatif mengonsumsi daging bagi efisiensi produksi dan lingkungan tidak berbeda secara signifikan dengan kontrolnya $(U=4,500 ; p>0,05$ dan $U=1,500 ; p>0,05)$. Hasil ini menyatakan bahwa rangsangan cukup efektif memprediksi perubahan perilaku mengonsumsi daging.

\section{ANALISIS DAN PEMBAHASAN}

Setiap grup eksperimen diberi paparan rangsangan berupa informasi tentang dampak negatif mengonsumsi daging pada kesehatan, efisiensi produksi, lingkungan, serta sosial dan etika. Grup kontrol tidak diberi rangsangan spesifik, melainkan hanya diberi informasi lisan. Pada akhir setiap sesi, sebagai tanda terimakasih telah berpartisipasi dalam penelitian, para partisipan dipersilakan mengambil satu dari dua pilihan kudapan (snack). Pilihan kudapan berupa kue donat (kudapan non daging) dan sosis daging (kudapan daging). Perubahan perilaku diukur dari pilihan kudapan daging atau non daging pasca sesi eksperimen. Pilihan kue donat diberi skor 1 dan pilihan sosis diberi skor 0. Skor 1 bermakna terjadi perubahan perilaku dan skor 0 bermakna tidak terjadi perubahan perilaku. Hasil eksperimen disajikan dalam Tabel 1 dan Tabel 2 .

Tabel 1

Uji Beda Perilaku

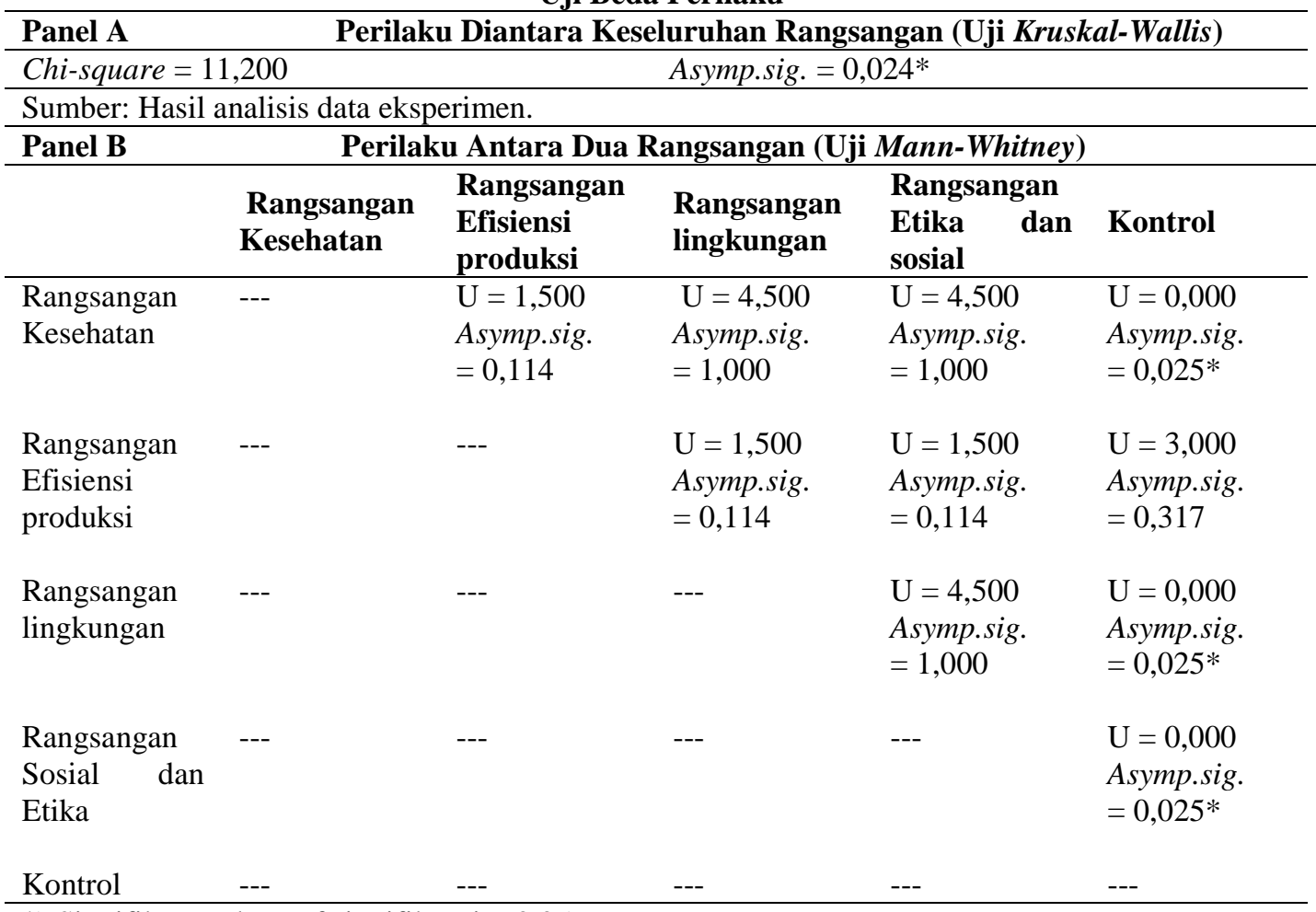

*) Signifikan pada taraf signifikansi $=0,05$ 
Tabel 1(Panel A) memperlihatkan hasil uji serentak dengan uji Kruskal-Wallis yang menyatakan ada beda signifikan di antara rangsangan penelitian termasuk kontrolnya (Chi-square $=11,200, \mathrm{p}<0,05$ ). Hasil mengindikasikan bahwa ada perubahan perilaku akibat paparan rangsangan. Tabel 1(Panel B) memperlihatkan hasil uji beda antar pasangan perlakuan penelitian. Uji Mann-Whitney dilakukan untuk mengidentifikasi rangsangan yang mampu menciptakan perubahan perilaku mengonsumsi daging. Rangsangan berupa informasi tentang dampak negatif mengonsumsi daging bagi kesehatan berbeda secara sinifikan dengan kontrolnya $(\mathrm{U}=0,000 ; \mathrm{p}<0,005)$. Rangsangan berupa informasi tentang dampak negatif mengonsumsi daging bagi lingkungan berbeda secara signifikan dengan kontrolnya $(\mathrm{U}=0,000 ; \mathrm{p}<0,005)$. Rangsangan berupa informasi dampak negatif mengonsumsi daging pada masalah sosial dan etika berbeda secara signifikan dengan kontrolnya $(\mathrm{U}=0,000 ; \mathrm{p}<0,05)$. Rangsangan berupa informasi tentang dampak negatif mengonsumsi daging bagi efisiensi produksi tidak berbeda secara signifikan dengan kontrolnya $(U=3,000 ; p>0,05)$. Hasil ini menyatakan bahwa rangsangan berupa informasi tentang dampak negatif mengonsumsi daging bagi kesehatan, lingkungan dan sosial dan etika mampu merubah perilaku mengonsumsi daging.

\section{Pembahasan}

Dalam perspektif teori pengondisian klasik, perubahan perilaku terjadi secara otomatis Allen dan Madden (1985) melalui transfer afek Zajonc dalam Allen dan Madden (1985) tanpa melibatkan kognisi. Tanggapan yang timbul bersifat emosional. Perubahan perilaku bersifat sementara. Bila partisipan sudah melupakan rangsangan, maka rangsangan tidak lagi efektif mengubah perilaku. Rangsangan berupa informasi dampak negatif mengonsumsi daging pada kesehatan, efisiensi produksi, lingkungan serta sosial dan etika ini berupaya mempengaruhi afek sehingga memunculkan tanggapan emosional dalam bentuk perilaku menghindari risiko akibat mengonsumsi daging.

Rangsangan berupa informasi tentang dampak negatif mengonsumsi daging pada kesehatan dibuat berdasarkan prinsip keengganan (menghindari risiko) akan mudah dikondisikan oleh cita rasa yang dilanjutkan dengan kesakitan. Rangsangan dikondisikan dibingkai keadaan positif, berupa pesan positif digabung dengan cita rasa daging. Rangsangan dikondisikan dilanjutkan dengan rangsangan tak dikondisikan berupa video yang menayangkan sekumpulan kejadian serangan jantung mendadak dan video jalannya operasi jantung. Tayangan video berhasil menggambarkan tingkat kesakitan yang tinggi pada penderita serangan jantung. Rangsangan diulang dua kali untuk menciptakan keterkaitan antara rangsangan dikondisikan dan rangsangan tak dikondisikan, terbukti mampu menghasilkan perubahan perilaku yang diharapkan, dimana selesai sesi eksperimen, seluruh partisipan memilih kudapan kue donat. Uji statistik hasil eksperimen menyatakan bahwa perubahan perilaku mengonsumsi daging akibat rangsangan berbeda secara signifikan dengan kontrolnya, sehingga 
dapat disimpulkan rangsangan mampu menciptakan perubahan perilaku mengonsumsi daging.

Rangsangan berupa informasi tentang dampak negatif mengonsumsi daging pada lingkungan dibuat berdasarkan prinsip bahwa keengganan terjadi akibat cahaya dan kebisingan kemudian dilanjutkan dengan kejutan. Rangsangan dikondisikan dibingkai keadaan positif, berupa pesan positif dengan latar belakang warna putih terang dan diiringi suara musik keras aliran trash metal berjudul Bestial Terror dari grup band metalika. Pemberian latar belakang musik cadas ini dimaksudkan untuk menciptakan suasana bising. Rangsangan dikondisikan dipasangkan dengan rangsangan tak dikondisikan berupa tayangan video runtuhnya perbukitan es di kutub serta runtuhnya bongkahan pulau es yang terbawa arus laut. Tayangan mampu menimbulkan keterkejutan dan kengerian, sehingga menciptakan tanggapan dikondisikan yang diinginkan. Seluruh partisipan memilih kudapan kue donat. Uji statistik hasil eksperimen menyatakan ada perubahan perilaku mengonsumsi daging secara signifikan.

Cara yang sama dilakukan pada penciptaan rangsangan berupa informasi tentang dampak negatif mengonsumsi daging pada masalah sosial dan etika. Rangsangan dikondisikan dipasangkan dengan rangsangan tak dikondisikan berupa tayangan video proses pemeliharaan dan penyembelihan hewan yang sangat kejam dalam industri peternakan unggas, sapi dan babi. Tayangan mampu menimbulkan keterkejutan dan kengerian, sehingga menciptakan tanggapan dikondisikan yang diinginkan. Seluruh partisipan memilih kudapan kue donat. Uji statistik hasil eksperimen menyatakan ada perubahan perilaku mengonsumsi daging secara signifikan.

Prinsip yang sama dilakukan pada pembuatan rangsangan berupa informasi tentang dampak negatif mengonsumsi daging pada efisiensi produksi. Rangsangan dikondisikan dipasangkan dengan rangsangan tak dikondisikan berupa tayangan tak bergerak yang berisi informasi pemborosan air, bahan bakar dan lahan pertanian untuk menghasilkan protein daging dibandingkan bila untuk menghasilkan protein nabati yang berasal dari tanaman. Namun rangsangan gagal menghasilkan perubahan perilaku. Uji statistik hasil eksperimen menyatakan bahwa tidak ada perbedaan perubahan perilaku antara kelompok eksperimen dengan kontrolnya. Kegagalan terjadinya tanggapan dikondisikan ini kemungkinan disebabkan: pertama, rangsangan tak dikondisikan adalah tayangan tak bergerak, kedua, informasi dalam rangsangan tak dikondisikan tidak menimbulkan efek kejut, sehingga syarat terjadinya tanggapan dikondisikan tidak dipenuhi.

Secara umum rangsangan penelitian berupa informasi tentang dampak negatif mengonsumsi daging pada kesehatan, lingkungan, serta masalah sosial dan etika berhasil merubah perilaku mengonsumsi daging. Maka hipotesis rangsangan berupa informasi tentang dampak negatif mengonsumsi daging pada kesehatan, lingkungan, serta sosial dan etika, mampu merubah perilaku konsumen dalam mengonsumsi daging, terdukung. 


\section{SIMPULAN, KETERBATASAN DAN SARAN}

\section{Simpulan}

Rangsangan berupa informasi tentang dampak negatif mengonsumsi daging pada kesehatan, lingkungan serta masalah sosial dan etika berhasil mengubah perilaku mengonsumsi daging secara signifikan. Sedangkan informasi tentang dampak negatif mengonsumsi daging pada efisiensi produksi gagal menciptakan perubahan perilaku mengonsumsi daging.

\section{Keterbatasan dan Saran}

Ukuran sampel dalam setiap kelompok eksperimen dan kontrol yang relatif sedikit (hanya tiga partisipan) dapat berpengaruh pada probabilitas penolakan hipotesis nol. Hal ini dapat berakibat pada kesimpulan yang berbeda bila penelitian menggunakan jumlah partisipan lebih besar. Oleh karena itu, penelitian serupa di masa depan perlu mengakomodasi penggunaan sampel besar, sehingga kesimpulan mempunyai kekuatan uji (power of test) tinggi.

\section{Implikasi Manajerial}

Pemerintah, masyarakat dan institusi bisnis mempunyai tanggung jawab untuk mendorong terciptanya perilaku konsumsi secara bertanggung jawab, dalam upaya menjaga kesinambungan (sustainability) sumber-sumber hayati bagi kesejahteraan manusia, hewan dan lingkungan. Pemerintah dan masyarakat dapat menggunakan rangsangan yang telah teruji ini untuk menciptakan metoda penyuluhan efektif untuk mengurangi perilaku mengonsumsi daging secara berlebihan, sehingga jumlah penderita hipertensi, jantung, kegemukan dan penyakit lain akibat mengonsumsi daging secara berlebihan, dapat diturunkan. Para pegiat pelestarian lingkungan dapat menggunakan hasil penelitian ini untuk membuat metoda kampanye pelestarian lingkungan yang efektif, guna mengurangi emisi gas rumah kaca yang menyumbang terjadinya perubahan iklim dan pemanasan global. Perusahaan yang menghasilkan produk pengganti daging (misal produk vegetarian) dapat menggunakan rangsangan yang dihasilkan penelitian ini untuk menciptakan kampanye iklan efektif untuk merekayasa perubahan perilaku beralih mengonsumsi produk pengganti daging.

\section{DAFTAR PUSTAKA}

Allen, CT, dan TJ Madden. 1985. “A Closer Look at Classical Conditioning.” Journal of Consumer Research 12 (3): 301-15. https://doi.org/10.1086/208517.

Assael, H. 2004. "Consumer Behavior: A Strategic Approach.” USA: Houghton Mifflin Company, 2004.

Benford, Robert D, dan D Snow. 2000. "Framing Processes and Social Movements: An overview and assesment." Annual Review of Sociology, 2000.

Bierley, Calvin, Frances K. McSweeney, dan Renee Vannieuwkerk. 1985. “Classical 
Conditioning of Preferences for Stimuli." Journal of Consumer Research 12 (3): 316-23. https://doi.org/10.1086/208518.

Carrington, Peter J., John Scott, dan Stanley Wasserman. 2005. Models and methods in social network analysis. Cambridge University Press. https://doi.org/10.2277/0521809592.

Frank, Joshua. 2007. "Meat as a bad habit: A case for positive feedback in consumption preferences leading to lock-in." Review of Social Economy 65 (3): 319-48. https://doi.org/10.1080/00346760701635833.

Hout, Marcel Van den, dan Harald Merckelbach. 1991. "Classical conditioning: Still going strong." Behavioural and Cognitive Psychotherapy 19 (1): 59-79.

Joyce, Andrew, Sarah Dixon, Jude Comfort, dan Jonathan Hallett. 2012. "Reducing the environmental impact of dietary choice: Perspectives from a behavioural and social change approach." Journal of Environmental and Public Health. https://doi.org/10.1155/2012/978672.

Keller, P.A, I. M Lipkus, dan B.K Rimer. 2003. “A behavior modification perspective on marketing." Journal of Marketing Research 40 (1): 54-64.

Koneswaran, Gowri, dan Danielle Nierenberg. 2008. "Global farm animal production and Global warming: Impacting and mitigating Climate Change." Environmental Health Perspectives $116 \quad$ (5): 578-82. https://doi.org/10.1289/ehp.11034.

McSweeney, Frances K., dan Calvin Bierley. 1984. "Recent Developments in Classical Conditioning." Journal of Consumer Research 11 (2): 619-31. https://doi.org/10.1086/208999.

Miniero, Giulia, Anna Codini, Michelle Bonera, Elisabetta Corvi, dan Giuseppe Bertoli. 2014. "Being green: From attitude to actual consumption." International Journal of Consumer Studies 38 (5): 521-28. https://doi.org/10.1111/ijcs.12128.

Nord, Walter R., dan J. Paul Peter. 1980. “A Behavior Modification Perspective on Marketing." Journal of Marketing 44 (2): 36-47. https://doi.org/10.2307/1249975.

Puto, Christopher P. 1987. “The Framing of Buying Decisions.” Journal of Consumer Research 14 (3): 301-15. https://doi.org/10.1086/209115.

Smil, Vaclav. 2002. "Eating Meat: Evolution, Patterns, and Consequences." Population and Development Review 28 (4): 599-639. https://doi.org/10.1111/j.1728-4457.2002.00599.x.

Zajonc, R. B. 1980. "Feeling and thinking: Preferences need no inferences." American Psychologist 35 (2): 151-75. https://doi.org/10.1037/0003-066X.35.2.151. 
